\title{
Sociocultural Activities: Tahfidz Al-Qur'an During Covid-19 Pandemic
}

\author{
Muhammad R. Asrori ${ }^{1, *}$ Ahmad F. Anam ${ }^{1,}$ Agus I. Mahmudi ${ }^{2,}$ M Ghufron ${ }^{1,}$ \\ M Syafiuddin ${ }^{1,}$ Indana Zulfa ${ }^{1}$
}

\author{
${ }^{1}$ MA Integratif NU Al-Hikmah, YPPI Jeru Tumpang, Malang, Indonesia \\ ${ }^{2}$ MA Al-Ittihad, YPP Al-Ittihad Poncokusumo, Malang, Indonesia \\ ${ }^{*}$ Corresponding author. Email: muhammadroyasrori09@gmail.com
}

\begin{abstract}
The striking development of Islamic education is the tahfidz Al-Qur'an program which has begun to be opened in formal institutions such as madrasa, Islamic schools, and Islamic boarding schools. During the COVID-19 Pandemic, tahfidz Al-Qur'an activities showed new obstacles and challenges. Daily activities may reflect the level of adaptation to pandemic conditions. For this reason, this study aims: (1) to determine the effectiveness of the tahfidz Al-Qur'an program on formal education during the COVID-19 pandemic in Islamic boarding schools (IBS), and (2) to explain the evaluation of the activities of tahfidz Al-Qur'an santri during the COVID-19 pandemic. This study used a qualitative approach because this study applied a case study form. The samples of this study were tahfidz Al-Qur'an santri (the students) and tahfidz Al-Qur'an teachers at MA Integratif NU Al-Hikmah. Primary data was carried out using several techniques, namely: in-depth interviews, field observations, and documentation. The secondary data was collected from journals and books. Furthermore, data analysis was carried out using descriptive analysis techniques. The results showed that tahfidz Al-Qur'an santri were constrained by conditions of time and place/room. Santri were still given tahfidz AlQur'an activities during the COVID-19 pandemic, but tahfidz Al-Qur'an learning and management were not optimal, and santri cannot performed memorization of the Qur'an to the teacher for a longer time, and health conditions and social activities were irregular. The pandemic has awakened the need for new adaptations in the tahfidz Al-Qur'an program.
\end{abstract}

Keywords: Daily activities, Formal education, Tahfidz Al-Qur'an, COVID-19 pandemic.

\section{INTRODUCTION}

Islamic education activities need to be considered as a character education institution and projected a golden generation of Indonesia. So far, the journey of Islamic education in Indonesia is still faced with problems from conceptual-theoretical to practical operations [1]. This education certainly encourages the modernization of Islamic education to suit the times and does not eliminate Islamic values [2]. The striking development of Islamic education is the tahfidz Al-Qur'an program which has begun to be opened in formal institutions such as madrasa, Islamic schools, and Islamic boarding schools [3]. This tahfidz Al-Qur'an program is often found and in demand by santri, namely Islamic boarding school (IBS) students. For current study, Islamic boarding school (IBS) is known as Pesantren (transl. Islamic boarding school/education) with the direction of Ahlussunnah wal Jama' $a h$ as in its history [4].

Tahfidz Al-Qur'an is an activity to keep, memorize and maintain the Qur'an [5]. Tahfidz Al-Qu'ran has provided positive character education, where santri are always instilled with the Quran so that they acquire 5 characters: religious, clean, istiqomah (persistence), discipline, and patient [6]. Tahfidz Al-Qur'an has become an educational program in several Indonesian Islamic education programs, and has even become a superior program in order to get used to the love of the Qur'an $[7,8]$. This is observed because of the emergence of parental concerns over children's addiction to gadgets/smartphones. This happens because of the rapid development of information and technology in the era of the industrial revolution 4.0, where the level of community adoption of foreign cultures that is easily 
accepted has a negative impact on children's character [9].

The results of the study report that there was a tendency for tahfidz. Al-Qur'an santri to obtain good learning processes and outcomes [10]. Reflecting on the real obstacles in 2020, namely the COVID-19 pandemic, where all Muslim activities changed drastically and experienced serious obstacles. Of course, this condition also affected the formal education of the tahfidz AlQur'an program. So, it is a special concern if santri who memorize the Qur'an have problems as long as they complete their memorization so that the current conditions need a good strategy in the tahfidz Al-Qur'an program.

Several previous studies that may underline this research were research that has explored the tahfidz AlQur'an learning process for early childhood [11]. Furthermore, research that has explored the tahfidz AlQur'an learning process for adolescents in extracurricular programs [12]. Then, research reported that the learning outcomes of tahfidz Al-Qur'an santri were relatively increased from before they took part in the tahfidz AlQur'an program [10]. This research was conducted before the COVID-19 pandemic. Research on the onlinebased tahfidz Al-Qur'an program at the Pondok Pesantren Taruna Al-Qur'an Putri Yogyakarta was known to provide a good solution during the COVID-19 pandemic [13]. The IBS was known to be equipped with adequate facilities as an integration of Islamic boarding schools and formal education in terms of the tahfidz AlQur'an program [14]. It is different with common madrasah/Islamic schools/Islamic boarding schools in general which still lack facilities, the tahfidz Al-Qur'an program needs to be systematically understood as researchers encountered in Jeru, Tumpang, Malang Regency.

Based on the description above, this study thoroughly explores the obstacles, learning motives, and complaints of tahfidz Al-Qur'an santri in memorizing the Qur'an during the COVID-19 pandemic in addition to the busyness of studying in formal schools/madrasa. The objectives of this study were (1) to determine the effectiveness of the tahfidz Al-Qur'an program on formal education during the COVID-19 pandemic in Islamic boarding schools (IBS), and (2) to explain the evaluation of the activities of tahfidz Al-Qur'an santri during the COVID-19 pandemic. This research is expected to provide a representation of tahfidz Al-Qur'an santri in formal learning that can find out the right educational strategy. In addition, this research can provide a comprehensive representation of the phenomenon of santri education with all its activities. In addition, related parties can provide evaluation, encouragement, support for the lives of santri as the next generation of the Indonesian nation.

\section{METHODS}

The type of the study was descriptive qualitative research. This study used a qualitative approach because this study applied a case study form [15]. So, this study described the empirical reality behind the phenomena studied in depth. This research was conducted at MA Integratif (Islamic integrated senior high school) NU AlHikmah and Islamic Boarding Schools (IBS) around the madrasah. The IBS applied the traditional IBS. The study was carried out in approximately 3 months.

The subject of this study consisted of the population and the sample; the population of this study was academic community of MA Integratif NU Al-Hikmah. Then, the sample of this study was tahfidz Al-Qur'an santri and tahfidz Al-Qur'an teachers at MA Integratif NU Al-Hikmah as many as 20 people. The data of this research were primary data and secondary data. Primary data were collected using several techniques, including in-depth interviews, field observations, and documentation. This study utilized the collected data in the form of words and actions [16].

To ensure the validity of the data, the researchers used the data triangulation method [17], namely data validity checking technique that utilizes something else. Data triangulation was applied to source triangulation and technique triangulation. Source triangulation in this study was an exploration to check the truth of data from various sources. Meanwhile, technique triangulation in this study was by examining data from the same source with different techniques. The secondary data was collected from the results of the study of literature from journals and books that relevant to this research.

Data analysis was carried out using descriptive analysis techniques, namely data collection in the form of words and not numbers [18]. In this case, the study used an interaction analysis model which was carried out in three stages, namely: (1) reducing data (summarizing, selecting, focusing on important things), (2) presenting data (displaying data in a systematic and easy-tounderstand way), and (3) drawing conclusions from the data displayed.

\section{RESULTS AND DISCUSSION}

\subsection{Activities of Tahfidz Al-Qur'am Santri during Formal Education}

Santri have a lot of activities because their activities always follow the schedule of religious activities from the IBS. Santri's activities aim to familiarize themselves in daily life with useful activities. Santri who violate the rules of IBS activities may lead into a simple punishment according to human rights. The santri's activities that have been observed were activities that have become 
their daily routine from early morning to midnight as shown in Table 1 below.

Table 1. Activities of santri in Jeru, Malang Regency

\begin{tabular}{|l|l|}
\hline \multicolumn{1}{|c|}{ Time Section } & \multicolumn{1}{|c|}{ Activities } \\
\hline Early days & $\begin{array}{l}\text { Wake up at night, pray, add } \\
\text { memorization of Qur'an }\end{array}$ \\
\hline Morning & $\begin{array}{l}\text { pray, murojaah, dzuha, formal } \\
\text { school }\end{array}$ \\
\hline Afternoon & Pray, early school \\
\hline Evening & Pray, rest \\
\hline Night & $\begin{array}{l}\text { Pray, read Al-Quran, dhikr \& } \\
\text { sholawat, and learn }\end{array}$ \\
\hline Midnight & Rest \\
\hline
\end{tabular}

Based on Table 1, the activities that have been carried out are quite dense. Between formal activities and ongoing religious activities, both male and female santri. Night time includes quiet time as an additional activity. In seeking peace, the researchers found that santri read at maqom, specifically grave of the founder of IBS. The activity of drinking coffee is enough to withstand the drowsiness. For female santri, midnight is the time for total sleep/rest. Diligent santri have added time to memorize the Qur'an at night and rest time.

\subsection{Impact of the COVID-19 Pandemic on the Tahfidz Al-Qur'an Program}

The COVID-19 pandemic has changed the activities of all areas of life, especially the tahfidz Al-Qur'an program. The tahfidz Al-Qur'an teacher explained that the tahfidz Al-Qur'an activities had been programmed in such a way that santri could complete their memorization of the Qur'an. The method used during the tahfidz AlQur'an program is the traditional method that santri memorize the Qur'an directly by habituation and reading. The pandemic condition calls for a re-programing of the tahfidz Al-Qur'an activities, including the application of the use of masks, maintaining distance, and class activities of no more than one hour. As for the boarding school, santri continue to memorize Al-Qur'an in conditions of room and time limitations according to health protocols. Some of the impacts of the pandemic on the tahfidz Al-Qur'an program are shown in Table 2.

Based on Table 2, the tahfidz program has experienced less serious impacts. The impact of the pandemic only affects the activities of santri to memorize the Qur'an. It is the activities of the santri who may determine their sincerity to complete the memorization of the Qur'an on scholarship opportunities, the scholarship organizers continue to open scholarships for tahfidz santri according to the capacity that have obtained. In short, the external support for the tahfidz program is still available during the COVID-19 pandemic.

Table 2. Impact of the COVID-19 pandemic on tahfidz Al-Qur'an programs

\begin{tabular}{|l|l|l|}
\hline \multicolumn{1}{|c|}{ Aspects } & \multicolumn{1}{|c|}{ Before Pandemic } & \multicolumn{1}{c|}{$\begin{array}{c}\text { During the } \\
\text { Pandemic }\end{array}$} \\
\hline Cost & Paid off & Pile up \\
\hline Environment & No health protocol & $\begin{array}{l}\text { Mandatory health } \\
\text { protocol }\end{array}$ \\
\hline Management & $\begin{array}{l}\text { Direct } \\
\text { administrative } \\
\text { control }\end{array}$ & $\begin{array}{l}\text { Administration } \\
\text { control must be } \\
\text { online }\end{array}$ \\
\hline Learning & $\begin{array}{l}\text { Can face to face, } \\
\text { interaction } \\
\text { between teachers } \\
\text { and santri can be } \\
\text { freely active }\end{array}$ & $\begin{array}{l}\text { Must be online, the } \\
\text { interaction } \\
\text { teachers and santri } \\
\text { is of } \\
\text { active }\end{array}$ \\
\hline $\begin{array}{l}\text { Tahfidz } \\
\text { Qur'an }\end{array}$ & $\begin{array}{l}\text { Success to final } \\
\text { Progress }\end{array}$ & \begin{tabular}{l} 
On the progress \\
\hline
\end{tabular} \\
\hline
\end{tabular}

\subsection{Formal Education of Tahfidz Al-Qur'an Santri during the COVID-19 Pandemic}

Formal education is a civic obligation. In terms of religion, formal education is education outside of Islamic boarding schools (IBS) with universal knowledge being studied; the law of studying universal knowledge after studying religion is fardlu kifayah. The results of the study provide support that tahfidz Al-Qur'an santri may easily understand the lesson. This is also supported as long as formal education activities are in synchronous with the activities at the IBS. The integrated tahfidz AlQur'an program in madrasah/school and Islamic boarding schools is a combination that has positive synergy that provides support for the complete memorization of the Qur'an.

During the COVID-19 pandemic, there has been more time to memorize the Qur'an, reduced social activities, and fluctuating health. So, during the COVID19 pandemic, the tahfidz Al-Qur'an program continued to held but it was not optimal in terms of learning and management of tahfidz Al-Qur'an program.

Several inhibiting factors in the application of learning tahfidz Al-Qur'an in formal education (madrasa/school), among others:

- Tahfidz Al-Qur'an management implemented by educational institutions includes time, place and 
environment management, as well as material for tahfidz Al-Qur'an;

- The activities of the Tahfidz Al-Qur'an teacher/instructor in guiding and motivating the tahfidz Al-Qur'an santri;

- the mechanisms and methods applied by the Tahfidz Al-Qur'an teacher; and

- control and motivation from managers of formal education units.

These results have similarities with Hidayah's findings about the causes of failure in the application of tahfidz Al-Qur'an learning in formal education [19]. The success of the Tahfidz Al-Qur'an program in an Islamic boarding schools can be a bridge towards achieving advantages over other disciplines. Therefore, the success of the Tahfidz Al-Qur'an program for educational institutions is important. Several important factors that may support the smooth quality of memorization of each santri, namely:

- talent and interest factors. Talent (aptitude) is the potential of santri to achieve success and preparation for the future,

- age factor greatly determines the ability of santri to memorize; childhood age is the best time to memorize the Qur'an.

- the intelligence factor is very supportive of santri so that they can quickly memorize the Qur'an.

- factor of a clean and solemn heart'. Al-Qur'an is the holy book of Allah revealed by Allah the Most Holy. Santri are avoided from negative thoughts

As described above, formal education will support santri learning if there is a balance of activities between schools and Islamic boarding school. A healthy environment will be able to foster healthy activities for santri [20].

\section{CONCLUSION}

The results of this study can be concluded as follows: (1) santri are given tahfidz Al-Qur'an activities during the COVID-19 pandemic but learning and management of tahfidz Al-Qur'an are not optimal, and (2) santri cannot performed the memorization of the Qur'an to the teacher for a longer time, as well as their health and condition. Social activities are irregular. So, the pandemic has awakened the need for new adaptations in the tahfidz Al-Qur'an program. The tahfidz Al-Qur'an program is still being held during the pandemic as a religious policy that aims to maintain religion.

\section{ACKNOWLEDGMENT}

On this occasion, the author would like to thank to MA Integratif NU Al-Hikmah by supporting this research on 2021. Then, thanks to Latifatul Rochimah and Masfufah as joining in this study.

\section{AUTHORS' CONTRIBUTIONS}

All authors have different roles in the accomplishment of the study. For this manuscript, they contributed equally to the process of drafting, revision, and approval of the final revision.

\section{REFERENCES}

[1] R. Awwaliyah, H. Baharun, Pendidikan Islam dalam Sistem Pendidikan Nasional (Telaah Epistemologi terhadap Problematika Pendidikan Islam), J. Ilm. Didakt., 19(1) (2018) 34-39. DOI: https://doi.org/10.22373/jid.v19i1.4193

[2] E. Elihami, Penerapan Pembelajaran Pendidikan Agama Islam dalam Membentuk Karakter Pribadi yang Islami, Edumaspul - J. Pendidik., 2(1) (2018) 79-96.

DOI:

https://doi.org/10.33487/edumaspul.v2i1.17

[3] A. Fatah, Dimensi Keberhasilan Pendidikan Islam Program Tahfidz Al-Qur'an, Edukasia J. Penelit. Pendidik. Islam, 9(2) (2014) 335-356. DOI: https://doi.org/10.21043/edukasia.v9i2.779

[4] A. Muhakamurrohman, Pesantren: Santri, Kiai, dan Tradisi, Ibda' J. Kebud. Islam, 12(2) (2014) 109118. DOI: https://doi.org/10.24090/ibda.v12i2.440

[5] A. Syahid, A. Wahyuni, Tren Program Tahfidz AlQur'an sebagai Metode Pendidikan Anak, Elem. J. Ilm. Pendidik. Dasar, 5(1) (2019) 87-96. URL: https://e-

journal.metrouniv.ac.id/index.php/elementary/articl e/view/1389

[6] M. Shobirin, Pembelajaran Tahfidz Al Qur'an dalam Penanaman Karakter Islami, Qual. J. Empir. Res. Islam. Educ., 6(1) (2018) 16-30. DOI: https://doi.org/10.21043/quality.v6i1.5966

[7] F. Hakim, Y. D. Permatasari, Tren: Pendidikan Tahfidz Qur'an pada Anak di Rumah Qur'an ArRoudhoh Rowotengah, J. Auladuna, 2(2) (2020) 1926. DOI: https://doi.org/10.36835/au.v2i2.375

[8] M. R. Asrori, Z. Fitriyah, A. F. Anam, A. N. A. Zubaidy, Z. Zubaidah, The Perception of Islamic Youth to The Phenomenon of Hubbu Ilahi, IJIK Int. J. Islam. Khazanah, 11(2) (2021) 61-66. DOI: https://doi.org/10.15575/ijik.v11i2.11866 
[9] Zulfitria, Peran Pembelajaran Tahfidz Al-quran Dalam Pendidikan Kkarakter Siswa, in Seminar Nasional Pendidikan Era Revolusi, 2018, pp. 301310 .

[10] S. Rofi, Analisis Perbedaan Hasil Belajar Siswa Mengikuti Program Tahfidz Al-Qur'an (Studi Kasus di SMP Muhammadiyah 9 Watukebo Jember), TARLIM J. Pendidik. Agama Islam, 2(1) (2019) 18.

[11] A. Maskur, Pembelajaran Tahfidz Alquran pada Anak Usia Dini, IQ (Ilmu Al-qur'an) J. Pendidik. Islam, 1(2) (2018) 188-198. DOI: https://doi.org/10.37542/iq.v1i02.15

[12] D. A. P. Wulan, Ismanto, Pembelajaran Ekstrakurikuler Tahfidz AL-Qur'an di Madrasah Aliyah, in The 1st Education and Language International Conference Proceedings, 2017, pp. 236-246.

URL: http://jurnal.unissula.ac.id/index.php/ELIC/article/ view/1235

[13] W. W. Mubarakah, E. Munastiwi, Pelaksanaan Program Tahfidz Al-Qur'an Berbasis Online Masa Pandemi Covid-19, Tadris J. Pendidik. Islam, 15(2) (2020) 184-194. DOI: https://doi.org/10.19105/tjpi.v15i2.3725

[14] N. Faqih, Integrasi Program Tahfidz dengan Sekolah Formal di Pondok Pesantren Anak, Al-Ta'dib J. Kaji. Ilmu Kependidikan, 13(2) (2020) 92-102. DOI: https://doi.org/10.31332/atdbwv13i2.1134

[15] Z. Arifin, Penelitian Pendidikan: Metode dan Paradigma Baru, Bandung: PT Remaja Rosdakarya, 2014.

[16] D. Satori, A. Komariah, Metodologi Penelitian Kualitatif, Bandung: Alfabeta, 2013.

[17] B. S. Bachri, Meyakinkan Validitas Data melalui Triangulasi pada Penelitian Kualitatif, J. Teknol. Pendidik, 10(1) (2010) 46-62.

[18] Sugiyono, Metode Penelitian Pendidikan (Pendekatan Kualitatif, Kuantitatif dan R\&D), Bandung: CV. Penerbit Alfabeta, 2015.

[19] N. Hidayah, Strategi Pembelajaran Tahfidz AlQur'an di Lembaga Pendidikan, Ta'allum, 4(1) (2016) 63-81. DOI: https://doi.org/10.21274/taalum.2016.4.1.63-81

[20] K. K. Schmeer, A. J. Yoon, Home sweet home? Home physical environment and inflammation in children, Soc. Sci. Res., 60 (2016) 236-248. DOI: https://doi.org/10.1016/j.ssresearch.2016.04.001 